\title{
ANTITUMOR EFFECT OF RADIATION THERAPY ON ORTHOTOPIC PDX MODELS OF HUMAN ESOPHAGEAL ADENOCARCINOMA
}

Kiblitskaya AA $\bowtie$, Goncharova AS, Anisimov AE, Snezhko AV, Dimitriadi SN, Maslov AA, Gevorkyan YA, Kolesnikov EN

National Medical Research Center for Oncology, Rostov-on-Don, Russia

As a rule, esophageal adenocarcinoma develops in the lower esophagus. Life expectancy and survival rates depend on the cancer stage and the general health of the patient. Chemoradiotherapy is the most successful treatment approach to this type of cancer. The choice of optimal radiation doses for achieving the best possible therapeutic effect is still a challenge. The aim of this paper was to study effective radiation doses and assess response of human esophageal adenocarcinoma to radiation using a PDX model. The study was conducted in female Balb/c nude mice $(n=25)$. Fragments of the donor tumor were implanted into the cervical esophagus of immunodeficient mice. Effects of radiation on the obtained orthotopic xenografts were studied after each of 3 irradiation sessions $(4,6,8$, and 10 Gy in each of the experimental groups, respectively). First-passage xenografts reproduced the morphology of the donor tumor. The mean tumor volume differed significantly between the control group and the experimental groups exposed to 6 , 8 or 10 Gy $(p \leq 0.01)$ after each irradiation session. Tumor growth delay was significant after exposure to the total dose of 18 Gy. The further radiation dose increase was ineffective. The reduction of tumor volume in the xenografts was correlated to the increase in the one-time radiation dose. The total dose over 18 Gy produced a detrimental effect on the hematopoietic system and blood biochemistry of the experimental mice.

Keywords: esophageal adenocarcinoma, orthotopic xenograft, radiotherapy, PDX-model, immunodeficient mouse

Author contribution: Kiblitskaya AA — data processing, manuscript preparation, technical editing, reference list, figures; Goncharova AS, Maslov AA — study concept and design, manuscript preparation; Anisimov AE — study concept and design, manuscript preparation, data acquisition, analysis and interpretation; Snezhko AV — content editing, manuscript preparation; Dimitriadi SN — data analysis and interpretation, technical editing; Gevorkyan YA — content editing; Kolesnikov EN — content and technical editing.

Ethical standards: the study fully complied with the principles of the Declaration of Helsinki; all requirements for animal housing were met; surgical interventions were conducted following the guidelines on the Care and Use of Laboratory Animals. The donors provided informed consent for their biological samples to be used in the study.

$\triangle$ Correspondence should be addressed: Alexandra A. Kiblitskaya

14 Liniya, 63, Rostov-on-Don, 344037, Russia; kibaleand@gmail.com

Received: 16.09.2021 Accepted: 04.10.2021 Published online: 20.10.2021

DOI: $10.24075 /$ brsmu.2021.047

\section{ПРОТИВООПУХОЛЕВОЕ ВЛИЯНИЕ ЛУЧЕВОЙ ТЕРАПИИ НА ОРТОТОПИЧЕСКУЮ РDХ-МОДЕЛЬ АДЕНОКАРЦИНОМЫ ПИЩЕВОДА ЧЕЛОВЕКА}

А. А. Киблицкая $\bowtie$, А. С. Гончарова, А. Е. Анисимов, А. В. Снежко, С. Н. Димитриади, А. А. Маслов, Ю. А. Геворкян, Е. Н. Колесников

Национальный медицинский исследовательский центр онкологии, Ростов-на-Дону, Россия

Аденокарцинома пищевода развивается, как правило, в нижней части органа. Продолжительность жизни и выживаемость при данном заболевании зависят от стадии патологического процесса и состояния здоровья пациента. Наиболее успешный метод для лечения аденокарциномы пищевода - химиолучевая терапия. Проблема подбора оптимальных доз облучения для получения максимального эффекта по сей день актуальна. Целью исследования было изучить эффективные дозы и оценить противоопухолевую активность лучевой терапии на ортотопическом PDX аденокарциномы пищевода человека. Исследование провели на самках мышей линии Balb/c nude ( $n=25)$. Ортотопическую трансплантацию осуществляли путем имплантации образцов опухоли пациента в шейный отдел пищевода иммунодесицитной мыши. Лучевое воздействие на ортотопические ксенографты исследовали в 3 этапа с кратностью облучения 1 раз в дозах 4, 6, 8 и 10 Гр. По результатам гистологического анализа ксенографты 1-й генерации воспроизводили основные морфологические характеристики опухоли пациента. Оценка динамики роста объемов опухолевых узлов экспериментальных животных позволяет сделать вывод, что у животных, облученных в однократной дозе 6, 8 или 10 Гр, средние значения объемов опухолевых узлов статистически значимо отличались $(p \leq 0,01)$ от значений в контрольной группе после каждой из трех процедур лучевого воздействия. По расчетам показателя торможения роста опухоли при суммарной дозе 18 Гр наблюдали значительное подавление роста опухоли. Дальнейшее повышение дозы лучевого воздействия было неэффективно. Установили, что снижение объемов опухолевых узлов в ксенографтах коррелирует с увеличением разовой дозы, при этом суммарная доза более 18 Гр пагубно влияет на систему кроветворения и биохимические показатели крови мышей.

Ключевые слова: аденокарцинома пищевода, ортотопический ксенографт, лучевая терапия, PDX-модель, иммунодесицитная мышь

Вклад авторов: А. А. Киблицкая - обработка материала, написание текста, техническое редактирование, оформление библиографии, подготовка иллюстраций; А. С. Гончарова, А. А. Маслов - концепция и дизайн исследования, подготовка статьи; А. Е. Анисимов - концепция и дизайн исследования, подготовка статьи, сбор, анализ и интерпретация данных, написание текста; А. В. Снежко - научное редактирование, подготовка статьи; С. Н. Димитриади - анализ и интерпретация данных, техническое редактирование; Ю. А. Геворкян — научное редактирование; Е. Н. Колесников научное редактирование, техническое редактирование

Соблюдение этических стандартов: исследование проведено с соблюдением требований Хельсинкской декларации; условия содержания животных соответствовали стандартам работы с животными; все хирургические манипуляции в эксперименте были выполнены с соблюдением «Правил проведения работ с использованием лабораторных животных». От пациентов было получено письменное информированное согласие на передачу биологического материала.

$凶$ Для корреспонденции: Александра Андреевна Киблицкая ул. 14-я линия, д. 63, г. Ростов-на-Дону, 344037, Россия; kibaleand@gmail.com

Статья получена: 16.09.2021 Статья принята к печати: 04.10.2021 Опубликована онлайн: 20.10.2021

DOI: $10.24075 /$ vrgmu.2021.047 
Esophageal cancer (EC) is an extremely aggressive malignancy and one of the leading causes of cancer mortality and morbidity worldwide [1]. Due to nodal involvement, the five-year survival rate is only $\sim 10-15 \%$ [2]. Risk factors for EC include consumption of hot foods and beverages, smoking, alcohol abuse, inhalation of toxic gases, exposure to drinking water contaminated with heavy metals, and ingestion of caustic substances [3].

There are 2 main histologic subtypes of EC: esophageal squamous cell carcinoma and esophageal adenocarcinoma (EAC) [4]. In Russia, squamous cell carcinoma is more common than EAC. However, the incidence of EAC localized to the distal esophagus or gastroesophageal junction has been on the rise in the past few years $[5,6]$. Unlike squamous cell carcinoma, EAC is characterized by early metastasis to regional lymph nodes and subserosal invasion with omental bursa involvement. This cancer rarely metastasizes to the liver [7]. It can spread to the submucosal lining of the thoracic esophagus, invading the diaphragm, pleura and pericardium. EAC is often characterized by exophytic growth, making surgical treatment difficult or lowly effective [8].

At present, chemoradiotherapy remains the optimal treatment approach to cervical esophageal cancer. Esophagectomy with pharyngogastric anastomosis often leads to postoperative complications and patient deterioration. The 5-year survival rate after chemoradiotherapy is $27 \%$ [9]. Two forms of radiation therapy are used: teletherapy and brachytherapy. Radiotherapy can be delivered perioperatively or in combination with chemotherapy. The instruments and methodology for radiotherapy have been refined over the years, but radioresistance observed in different histological types of EC still remains a serious challenge.

In theory, high doses of radiation will increase the probability of a more pronounced cytotoxic effect. In practice, tumor breakdown products are toxic to the patient and disrupt their homeostasis. This raises the question as to what radiation methods and optimal doses should be used to achieve the maximum antitumor effect with minimal harm to the patient.

One of the hurdles to the improvement of treatment efficacy for human EAC is the absence of reliable preclinical models for translational studies [10]. Traditional experimental models, like cell-line derived xenografts injected subcutaneously or directly into the esophageal wall of immunodeficient mice, do not recapitulate the intratumoral heterogeneity of the donor tumor [11]. By contrast, patient-derived xenograft (PDX) models hold promise for developing novel strategies for cancer treatment [12].

In a PDX model, fragments of the donor tumor are implanted into immunodeficient mice [13]. Translational cancer studies utilize athymic Bald/c nude mice carrying the Foxn1 mutation [14, 15]. Immune deficiency due to T-cell deficit facilitates successful engraftment and metastasis of the donor tumor [16]. PDX models retain morphological characteristics and heterogeneity of the donor tumor and therefore predict the patient's response to treatment better than cell line-derived xenografts [17]. Although the human stroma is replaced with the murine stroma in a PDX model, the model retains intratumor heterogeneity through multiple passages [18].

Because of their technical simplicity, heterotypic (subcutaneous) PDX models are extensively used in translational cancer research. However, subcutaneous xenografts do not reproduce the initial microenvironment of the donor tumor, are subject to encapsulation, advance locally, and do not metastasize [19].

An orthotopic PDX model of human EAC is generated by direct implantation of the tumor fragment into the distal

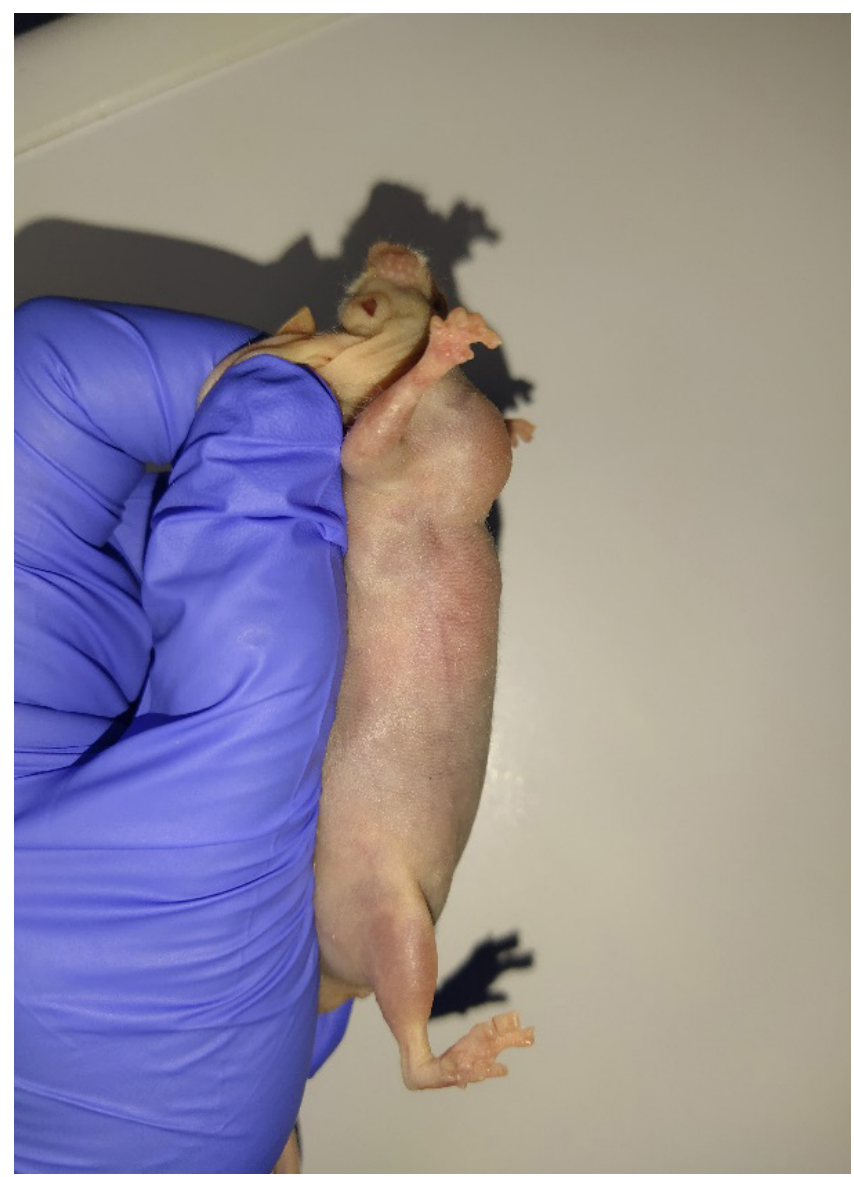

Fig. 1. The orthotopic PDX model of human esophageal adenocarcinoma (passage 6)
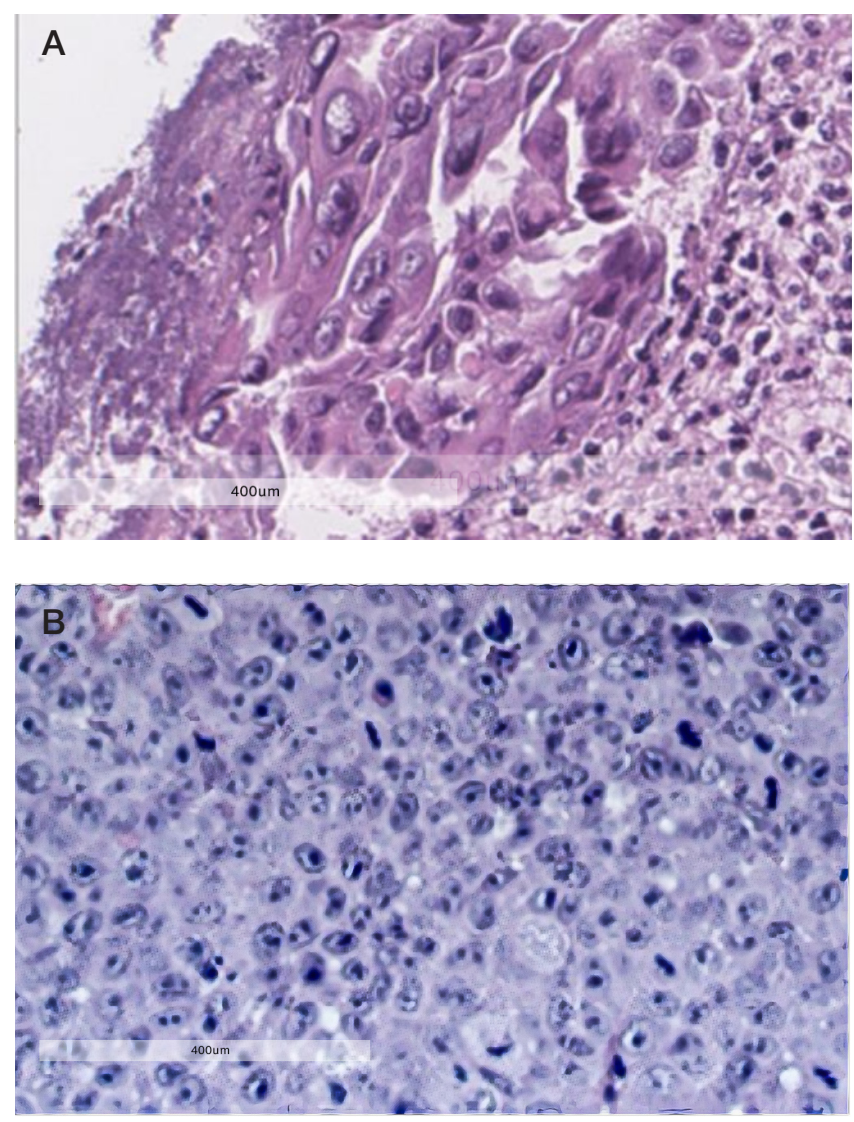

Fig. 2. Histology slices of moderately differentiated human EAC. A. The donor tumor. B. The orthotopic xenograft, passage 1. Hematoxylin-eosin staining; $\times 400$ 
esophageal wall of the mouse. The growing nodule and the effect of radiotherapy are easily measurable; yet, the anatomy and size of the murine esophagus make this cancer model technically sophisticated [20]. The esophageal wall provides a specific microenvironment to EAC, so the model can recapitulate the pathomorphologic and molecular features of the donor tumor [21]. Consequently, orthotopic PDX models are employed in the studies of tumor behavior and therapeutic approaches to cancer. In our experiment, the anticancer effect of radiotherapy was measured based on tumor growth delay (TGD) [22].

The aim of this paper was to study effective radiation doses for EAC treatment and assess response of human EAC to radiation using a PDX model generated by transplanting fragments of the donor tumor into the cervical esophagus of immunodeficient mice.

\section{METHODS}

The study was conducted at Rostov Cancer Research Institute. Orthotopic xenografts were prepared from fresh tumor material collected from a donor patient with EAC. The first 5 preparatory passages were conducted in 12 female Balb/c nude mice. The final 6th passage was conducted in 25 female Balb/c nude mice (age: 6-8 weeks, weight: 21-25 g). The animals were housed in an SPF animal facility in individually ventilated cages at $22-24^{\circ} \mathrm{C}$ and $60 \%$ humidity under $12 / 12$ light/dark conditions. At the end of the experiment, the animals were sacrificed in a $\mathrm{CO}_{2}$ chamber; the tumors were immediately harvested for further manipulations.

EAC response to radiation was studied using orthotopic PDX tissue from passage 6 (Fig. 1). Xenografts were exposed to radiation once they reached $100 \mathrm{~mm} 3$ in size on day 30 after transplantation. The mice were divided into 5 groups: the control group and intervention groups 1, 2, 3, and 4 subjected to different radiation regimens. Each group consisted of 5 animals. Group 1 received a total dose of 12 Gy delivered in 3 fractions (4 Gy each); group 2, 18 Gy delivered in 3 fractions (6 Gy); group 3, 24 Gy delivered in 3 fractions (8 Gy); group 4, 30 Gy delivered in 3 fractions (10 Gy). The experiment lasted for 7 days. Irradiation was performed on the Xstrahl $150 \mathrm{X}$-ray system (Xstrahl; UK) with an $0.2 \mathrm{~mm}$ Al filter and $1.5 \mathrm{~cm}$ and 2 $\mathrm{cm}$ applicators.

Tumor dimensions were measured with a caliper. Tumor volume was calculated using the following ellipsoid formula:

$$
\mathrm{V}=\mathrm{a} \times \mathrm{b} \times \mathrm{c} \times \pi / 6
$$

where $\mathrm{V}$ is tumor volume $\left(\mathrm{mm}^{3}\right)$; $\mathrm{a}, \mathrm{b}, \mathrm{c}$ are the maximum diameters of the ellipsoid in 3 planes $(\mathrm{mm})$.

Tumor growth delay was calculated by the formula:

$$
\mathrm{TGD}=\left(\mathrm{V}_{\text {control }}-\mathrm{V}_{\text {exper }}\right) / \mathrm{V}_{\text {control }} \times 100 \text {. }
$$

Hematology tests were performed using an Exigo veterinary hematology analyzer (BouleMedical; USA). Biochemistry tests were performed using a VETSCANVS2 analyzer (Zoetis; USA).

Statistical analysis was conducted in STATISTICA 10. Quantitative variables are presented below as means and standard deviations $\mathrm{M} \pm \mathrm{SD}$. Differences between the means of each 2 independent variables were assessed using the MannWhitney $U$ and the Wilcoxon rank-sum tests.

\section{Orthotopic transplantation of donor tumor to the esophagus of immunodeficient mice}

For the transplantation procedure, the animals were premedicated with intramuscularly administered xylazine hydrochloride $(20 \mathrm{mg} / \mathrm{g})$ and anesthetized 15 min later with an intramuscular injection of tiletamine hydrochloride and zolazepam hydrochloride $(22.57 \mathrm{mg} / \mathrm{g})$.

Prior to surgery, samples of the donor tumor were divided into $\sim 27 \mathrm{~mm}^{3}$ fragments; patches of necrotized tissue were removed in advance. The fragments were transplanted $30 \mathrm{~min}$ after resection. The skin at the surgical site was treated with a povidone-iodine solution 10\%.

To access the esophagus, a neck skin incision was made from the right ear base to the left ear base. The trachea and the underlying esophagus were isolated using blunt dissection. The adventitia and the muscular layer were dissected with a scalpel. The tumor fragment was sutured to the esophageal wall above the incision using 5-0 Prolene sutures. The wound was closed with Glover's suture [23].

After the transplanted tumor reached $150-250 \mathrm{~mm}^{3}$ in size, it was harvested and passaged. A total of 6 passages were performed.

\begin{tabular}{|c|c|c|c|c|c|c|c|c|c|}
\hline \multirow{2}{*}{ Group } & \multirow{2}{*}{ Parameter } & \multicolumn{2}{|c|}{ Day 0} & \multicolumn{2}{|c|}{ Day 1} & \multicolumn{2}{|c|}{ Day 5} & \multicolumn{2}{|c|}{ Day 7} \\
\hline & & $\mathrm{V}, \mathrm{mm}^{3}$ & Weight, g & $\mathrm{V}, \mathrm{mm}^{3}$ & Weight, g & $\mathrm{V}, \mathrm{mm}^{3}$ & Weight, g & $\mathrm{V}, \mathrm{mm}^{3}$ & Weight, g \\
\hline \multirow[b]{2}{*}{ Control } & Mean & 86 & 21 & 626 & 22.7 & 1250.7 & 22.3 & 2136.6 & 22.3 \\
\hline & $\begin{array}{l}\text { Standard } \\
\text { deviation }\end{array}$ & 2.8 & 0.5 & 4.9 & 0.3 & 148.5 & 0.8 & 74.5 & 0.8 \\
\hline \multirow[b]{2}{*}{1 (4 Gy) } & Mean & $91.1^{*}$ & 21.7 & $554.8^{\circ}$ & 23 & $1052.0^{*}$ & 21.1 & $1145.9^{\circ}$ & 21.1 \\
\hline & $\begin{array}{l}\text { Standard } \\
\text { deviation }\end{array}$ & 2.4 & 0.6 & 9 & 0.4 & 72.9 & 1.2 & 120.7 & 1 \\
\hline \multirow{2}{*}{2 (6 Gy) } & Mean & 88 & 20.5 & $235.1^{\circ}$ & 22.2 & $249.3^{\circ}$ & 22.7 & $248.1^{\circ}$ & 22.5 \\
\hline & $\begin{array}{l}\text { Standard } \\
\text { deviation }\end{array}$ & 1.6 & 0.5 & 2.7 & 0.8 & 2 & 0.8 & 1.3 & 1.2 \\
\hline \multirow[b]{2}{*}{3 (8 Gy) } & Mean & $80.9^{*}$ & 22.2 & $210.8^{\circ}$ & 23.5 & $228.9^{\circ}$ & 23.5 & $227.8^{\circ}$ & 23.5 \\
\hline & $\begin{array}{l}\text { Standard } \\
\text { deviation }\end{array}$ & 2 & 0.4 & 5.8 & 0.4 & 14 & 0.5 & 8.2 & 0.5 \\
\hline \multirow[b]{2}{*}{4 (10 Gy) } & Mean & 89.5 & 21.5 & $195.2^{\bullet}$ & 22.7 & $200.1^{\circ}$ & 19.7 & $198.9^{\circ}$ & 19.8 \\
\hline & $\begin{array}{l}\text { Standard } \\
\text { deviation }\end{array}$ & 2.8 & 0.8 & 6 & 1.3 & 3.3 & 3 & 4.4 & 0.9 \\
\hline
\end{tabular}

Table 1. Mean EAC xenograft volumes and mouse body weight in the control and experimental groups

Note: * — differences are significant between groups 1 (4 Gy), 2 (6 Gy), 3 (8 Gy), 4 (10 Gy) and the control group; Mann-Whitney U test ( $p<0.05$ ); • — differences are significant between groups 1 (4 Gy), 2 (6 Gy), 3 (8 Gy), 4 (10 Gy) and the control group; Mann-Whitney U test $(p \leq 0,01)$. 


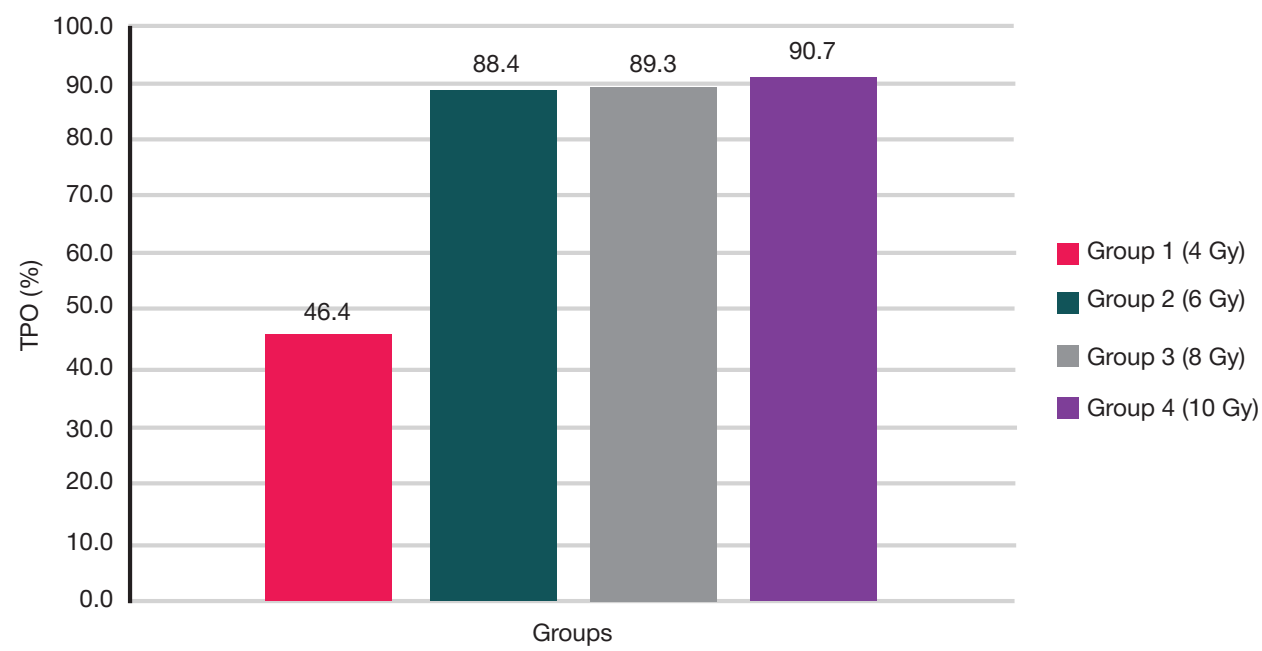

Fig. 3. TGW of the PDX model of human EAC in the experimental groups of mice irradiated with 4 Gy (group 1), 6 Gy (group 2), 8 Gy (group 3), and 10 Gy (group 4)

\section{RESULTS}

Engraftment was improving with each passage. At passages 1,2 and 3, the rate of engraftment was 55\%, 70\% and $80 \%$, respectively. From passage 4 to passage 6 , orthotopic xenograft survival was $100 \%$.

\section{Histologic verification of human EAC PDX models}

Histologically, the donor tumor was a moderately differentiated adenocarcinoma. Along with typical adenocarcinoma cells, the sample contained atypical spindle-shaped cells with karyopyknotic or karyorrhectic nuclei. First-passage xenografts reproduced the main characteristics of the donor tumor quite well and were histologically a moderately differentiated adenocarcinoma, with mostly typically shaped cells with degenerative nuclei or pathologic mitoses (Fig. 2).

\section{Effects of radiation on orthotopic xenografts of human EAC}

The mean xenograft volumes and the mean weight of mice in the control and experimental groups are provided in Table 1. After the 1st and 3rd irradiation sessions, significant differences in the mean xenograft volume were observed between group 1 (4 Gy) and the untreated control group ( $p \leq 0.01$ ). Significant differences $(p \leq 0.01)$ in the mean tumor volume were also registered after each irradiation session between the control group and the experimental groups subjected to different irradiation regimens (one-time doses of 6, 8 and 10 Gy). On day 7 , the tumors stopped growing at 248.1, 227.8 and 198.9 mm3 in groups receiving 6, 8 and 10 Gy fractions, respectively; these sizes differed significantly from tumor sizes in the control group.

Table 2. Complete blood counts on day 25 of the experiment
No reliable differences in body weight dynamics were observed between the groups throughout the experiment. The mean body weight ranged from $19.7 \pm 3.0 \mathrm{~g}$ to $23.5 \pm 0.5 \mathrm{~g}$. This suggests that the studied radiation doses did not produce a considerable impact on the animal weight.

At the end of the experiment, TGD was 46.4, 88.4, 89.3, and $90.7 \%$ in groups $1,2,3$, and 4 , respectively (Fig. 3). The analysis revealed that the total dose of 18 Gy caused a significant tumor growth delay; so, it may be ineffective to further increase the delivered dose due to the adverse effects of radiation.

Clinical examination of group 4 that had received the total radiation dose of 30 Gy revealed the presence of tumor necrosis. The tumors produced milky-colored discharge and were ulcerating on the surface. In the control group, the tumors were larger, dark purple-blue, well-vascularized, without signs of necrosis or ulceration.

According to the pathomorphological examination of tumor fragments subjected to the total radiation dose of 30 Gy, glandular cells were undergoing transformation without keratinization; there was pronounced tissue necrosis ( 50\% of the total sample area) and sites of pathological mitosis. Besides, there were cells undergoing karyolysis and cytolysis (Fig. 4).

\section{Hematological and biochemical blood profile of orthotopic PDXs of human EAC after irradiation}

After the full course of irradiation was completed, hematological profiles of the irradiated mice were prepared (Table 2).

The average hemoglobin concentration was inversely proportional to the applied radiation dose and differed between the control group and groups 1, 2, 3 and $4(p<0.01)$. Total red blood cell, white blood cell, lymphocyte, monocyte and platelet counts were lower in the experimental groups. Specifically,

\begin{tabular}{|c|c|c|c|c|c|c|}
\hline Group & Hemoglobin & Platelets & White blood cells, $10^{\circ} / \mathrm{L}$ & Lymphocytes, $10 \% / \mathrm{L}$ & Monocytes, $10^{9} / \mathrm{L}$ & Red blood cells, $10^{\%} / \mathrm{L}$ \\
\hline Control & $118 \pm 4.9$ & $481 \pm 79$ & $3.7 \pm 0.6$ & $1.6 \pm 0.4$ & $0.9 \pm 0.2$ & $6.8 \pm 0.5$ \\
\hline $1(4 \mathrm{~Gy})$ & $115 \pm 4.3^{*}$ & $477 \pm 60^{*}$ & $3.3 \pm 0.5^{*}$ & $1.4 \pm 0.4$ & $0.85 \pm 0.2$ & $6.6 \pm 0.4$ \\
\hline $2(6 \mathrm{~Gy})$ & $111 \pm 4.4^{*}$ & $474 \pm 55^{*}$ & $3.0 \pm 0.4^{*}$ & $1.2 \pm 0.3^{*}$ & $0.7 \pm 0.3$ & $6.0 \pm 0.4^{*}$ \\
\hline $3(8 \mathrm{~Gy})$ & $99 \pm 5.8^{*}$ & $470 \pm 58^{*}$ & $2.7 \pm 0.4^{*}$ & $1.0 \pm 0.4^{*}$ & $0.5 \pm 0.2^{*}$ & $5.7 \pm 0.4^{*}$ \\
\hline $4(10 \mathrm{~Gy})$ & $93 \pm 3.9^{*}$ & $464 \pm 52^{*}$ & $2.5 \pm 0.3^{*}$ & $0.7 \pm 0.1^{*}$ & $0.4 \pm 0.1^{*}$ & $5.2 \pm 0.3^{*}$ \\
\hline
\end{tabular}

Note: * - differs from the control group, $p<0.01$; the Wilcoxon rank sum test. 
lymphocyte, monocyte and platelet counts were significantly lower in groups 2, 3 and $4(p<0.01)$, whereas red and white blood cell counts differed significantly between the control group and groups $1,2,3$, and $4(p<0.01)$.

Results of the blood biochemistry test are provided in Table 3. Differences in total protein were significant between the control group and groups 2, 3 and $4(p<0.01)$. The increase in the delivered radiation dose led to a gradual rise in urea, creatinine and alanine aminotransferase concentrations; differences in these blood parameters between the control group and the groups exposed to 8 and 10 Gy were statistically significant $(p<0.01)$. The shifts in the biochemical profile of the irradiated animals can be explained by active necrosis developing in the irradiated tumors. Blood sugar did not differ significantly between the groups. Alkaline phosphatase in groups 1, 2,3 , and 4 was significantly lower $(p<0.01)$ than in the control group. Reduced alkaline phosphatase activity can be explained by a decline in hemoglobin concentrations observed in all experimental groups. After the radiation dose totaled to 24 Gy, the animals became less active and acquired a hunch posture.

\section{DISCUSSION}

There is an interesting publication investigating the antitumor effect of a combination therapy with fractionated radiation (3 × 2 Gy) and intraperitoneally administered TH-302 (50 mg/kg) on the subcutaneous xenografts of esophageal squamous cell carcinoma (OE21) and EAC (OE19) [24]. The study has demonstrated a significant tumor growth delay for OE19 $(p=0.02)$ and OE21 $(p=0.03)$ cancers following a combination therapy with $\mathrm{TH}-302$ and fractionated radiation, as compared with radiation therapy alone. The models generated through the subcutaneous implantation of cancer cells lacked intratumor heterogeneity typical for human carcinomas. This means that preclinical data may differ significantly from the results of clinical studies [12].

According to another study, a combination of PI3K $\alpha$ selective inhibitor $\mathrm{CYH3}$ and radiotherapy produces a synergic inhibiting effect on the growth of subcutaneous xenografts of human esophageal squamous cell carcinoma [25]. Although subcutaneous xenografts created from the fragments of human donor tumors retained the heterogeneity of the donor material, the site of heterotopic implantation precluded mimicking the microenvironment of the donor tumor, blocked metastasis and did not reproduce the major signaling pathways involved in oncogenesis.

Table 3. Results of blood biochemistry tests on day 25 of the experiment
In this study, we used the orthotopic model of human EAC since it is the closest to the actual patient's clinical response to therapy [26]. The choice of the model allowed us to study how exposure to radiation affected the growth of the obtained xenografts and to establish its dose-depending effect. In earlier works, PDX models of human tumors were studied as potential models for metastasis and were not used to evaluate the effects of radiation [27].

\section{CONCLUSIONS}

After each irradiation session, the average tumor volume differed significantly between the experimental groups exposed to 6,8 and 10 Gy and the control group ( $p \leq 0.01)$. At the end of the experiment, TGD was 46.4, 88.4, 89.3 and $90.7 \%$ in groups 1, 2, 3, and 4, respectively. Although the body weight did not change throughout the experiment in any of the groups, exposure to radiation had a detrimental dose-dependent effect on the health of the experimental animals manifesting in their low complete blood counts and blood biochemistry tests. Exposure to the total radiation dose over 18 Gy resulted in reduced hemoglobin, low red and white blood cell counts, increased degradation of protein molecules in the setting of tumor necrosis. Therefore, further in vivo research of radiation therapy alone or in combination with antitumor agents using murine models of human EAC should not use the total radiation dose of over 18 Gy, considering the harm it does to the animal's health.

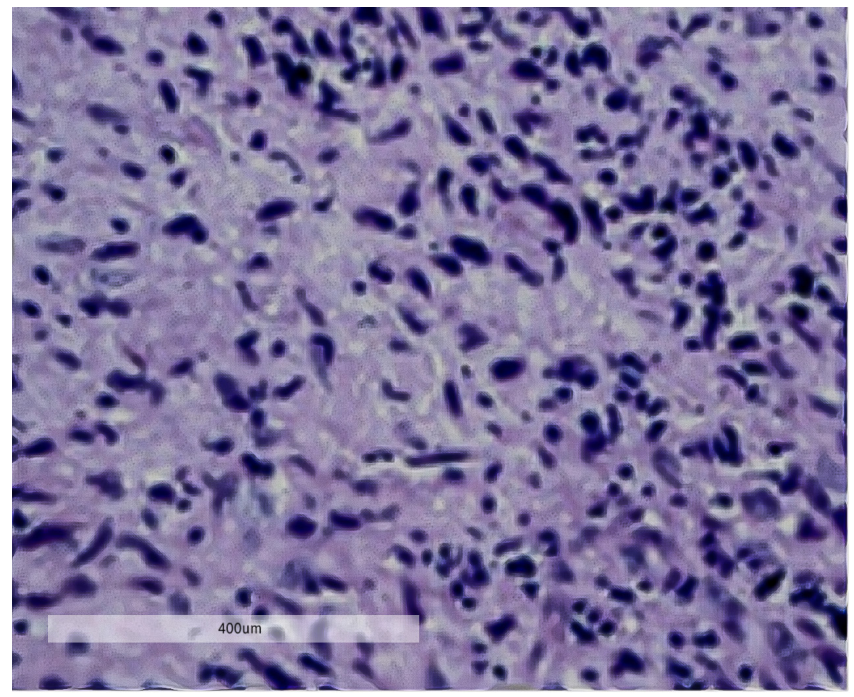

Fig. 4. Histology slices of the PDX model of human EAC generated in Balb/cNude mice after irradiation with a total dose of 30 Gy. Hematoxylin-eosin staining; $\times 400$

\begin{tabular}{|c|c|c|c|c|c|c|}
\hline Group & Protein, $\mathrm{mg} / \mathrm{dL}$ & $\begin{array}{c}\text { Urea nitrogen, } \\
\mathrm{mg} / \mathrm{dL}\end{array}$ & $\begin{array}{c}\text { Creatinine, } \\
\mathrm{mg} / \mathrm{dL}\end{array}$ & Glucose, $\mathrm{mg} / \mathrm{dL}$ & ALT, un/L & ALP, un/L \\
\hline Control & $5.4 \pm 0.3$ & $0.4 \pm 0.1$ & $0.6 \pm 0.05$ & $190 \pm 14$ & $51 \pm 6.7$ & $65 \pm 8.2$ \\
\hline 1 (4 Gy) & $5.5 \pm 0.3$ & $0.5 \pm 0.1$ & $0.75 \pm 0.1$ & $185 \pm 15$ & $53 \pm 7$ & $62 \pm 4.8^{\star}$ \\
\hline 2 (6 Gy) & $5.7 \pm 0.5^{*}$ & $0.6 \pm 0.2$ & $0.9 \pm 0.1^{*}$ & $189 \pm 10$ & $58 \pm 6.5^{\star}$ & $63 \pm 4^{*}$ \\
\hline 3 (8 Gy) & $6.1 \pm 0.4^{*}$ & $0.8 \pm 0.1^{*}$ & $1.2 \pm 0.2^{*}$ & $192 \pm 16$ & $59 \pm 8.6^{*}$ & $61 \pm 5.5^{*}$ \\
\hline $4(10$ Gy) & $6.3 \pm 0.4^{*}$ & $1.1 \pm 0.3^{*}$ & $1.3 \pm 0.1^{*}$ & $191 \pm 12$ & $62 \pm 6.7^{*}$ & $55 \pm 7.5^{\star}$ \\
\hline
\end{tabular}

Note: * — differs from the control group, $p<0.01$; the Mann-Whitney $U$ test. ALT — alanine aminotransferase; ALP — alkaline phosphatase. 
1. Gladilina IA, Tryakin AA, Zahidova FO, Malihova OA, Ivanov SM, Kravec OA, i dr. Rak pishhevoda: jepidemiologija, faktory riska i metody diagnostiki. Onkologicheskij zhurnal: luchevaja diagnostika, luchevaja terapija. 2020; 3 (1): 69-76. Russian.

2. Ho ALK, Smyth EC. A global perspective on esophageal cancer: two diseases in one. The Lancet Gastroenterology \& Hepatology. 2020; 5 (6): 521-2. DOI: 10.1016/S2468-1253(20)30047-9.

3. Enzinger PC, Mayer RJ. Esophageal cancer. New England Journal of Medicine. 2003; 349 (23): 2241-52.

4. Lin EW, Karakasheva TA, Hicks PD, Bass AJ, Rustgi AK. The tumor microenvironment in esophageal cancer. Oncogene. 2016; 35 (41): 5337-49.

5. Aksel EM. Statistika zlokachestvennyh novoobrazovanij zheludochno-kishechnogo trakta. Sibirskij onkologicheskij zhurnal. 2017; 16 (3): 5-11. DOI: 10.21294/1814-4861-2017-3-5-11. Russian.

6. Kit OI. Nejrojendokrinnye, klinicheskie i morfologicheskie aspekty raka zheludka. Novocherkassk: Lik, 2014; 221 s. Russian.

7. Ishihara R, Oyama T, Abe S, Takahashi H, Ono H, Fujisaki J et al. Risk of metastasis in adenocarcinoma of the esophagus: a multicenter retrospective study in a Japanese population. Journal of gastroenterology. 2017; 52 (7): 800-8. DOI: 10.1007/s00535016-1275-0.

8. Mahoney JL, Condon R. E. Adenocarcinoma of the esophagus. Annals of surgery. 1987; 205 (5): 557.

9. Urmonov UB, Dobrodeev AYu, Afanasev SG, Avgustinovich AV, Cheremisina OV. Sovremennye aspekty lechenija raka pishhevoda. Sibirskij onkologicheskij zhurnal. 2019; 18 (4): 78-84. DOl: 10.21294/1814-4861-2019-18-4-78-84. Russian.

10. Hidalgo M, Amant F, Biankin AV, Budinská E, Byrne AT, Caldas C, et al. Patient-derived xenograft models: an emerging platform for translational cancer research. Cancer Discov. 2014; 4: 998-1013. DOI: 10.1158/2159-8290.

11. Wilding JL, Bodmer WF. Cancer Cell Lines for Drug Discovery and Development. Cancer Res. 2014; 74 (9): 2377-84. DOl: 10.1158/0008-5472.CAN-13-2971.

12. Sung-Yup Cho. Patient-derived xenografts as compatible models for precision oncology. Laboratory Animal Research. 2020; 36: 14. DOI: $10.1186 / s 42826-020-00045-1$.

13. Zhuo J, Su R, Tan W, Lian Z, Lu D, Xu X. The ongoing trends of patient-derived xenograft models in oncology. Cancer Commun (Lond). 2020; 40 (11): 559-63. DOI: 10.1002/cac2.12096.

14. Fernandes DP, Pimentel MML, Santos FAD, Praxedes ÉA, Brito PD, Lima MA, Lelis ICNG, Macedo MF, Bezerra MB. Hematological and biochemical profile of BALB/c nude and C57BL/6 SCID female mice after ovarian xenograft. An Acad Bras Cienc. 2018; 90 (4): 3941-48. DOI: 10.1590/0001-3765201820180586.

15. Zhukova GV, Shihlyarova Al, Sagakyanc AB, Protasova TP. O rasshirenii variantov ispol'zovanija myshej BALB/c nude dlja jeksperimental'nogo izuchenija zlokachestvennyh opuholej cheloveka in vivo. Juzhno-Rossijskij onkologicheskij zhurnal.

\section{Литература}

1. Гладилина И. А., Трякин А. А., Захидова Ф. О., Малихова О. А., Иванов С. М., Кравец О. А. и др. Рак пищевода: эпидемиология, факторы риска и методы диагностики. Онкологический журнал: лучевая диагностика, лучевая терапия. 2020; 3 (1): 69-76.

2. Ho ALK, Smyth EC. A global perspective on esophageal cancer: two diseases in one. The Lancet Gastroenterology \& Hepatology. 2020; 5 (6): 521-2. DOI: 10.1016/S2468-1253(20)30047-9.

3. Enzinger PC, Mayer RJ. Esophageal cancer. New England Journal of Medicine. 2003; 349 (23): 2241-52.

4. Lin EW, Karakasheva TA, Hicks PD, Bass AJ, Rustgi AK. The tumor microenvironment in esophageal cancer. Oncogene. 2016; 35 (41): 5337-49.

5. Аксель Е. М. Статистика злокачественных новообразований желудочно-кишечного тракта. Сибирский онкологический
2020; 1 (2): 28-35. Russian.

16. Szadvari I, Krizanova O, Babula P. Athymic nude mice as an experimental model for cancer treatment. Physiol Res. 2016; 65 (Suppl 4): S441-53. DOI: 10.33549/physiolres.933526.

17. Pompili L, Porru M, Caruso C, Biroccio A, Leonetti C. Patientderived xenografts: a relevant preclinical model for drug development. J Exp Clin Cancer Res. 2016; 35 (1): 189. DOI: 10.1186/s13046-016-0462-4.

18. Choi YY, Lee JE, Kim H, Sim MH, Kim K.-K., Lee G, et al. Establishment and characterisation of patient-derived xenografts as paraclinical models for gastric cancer. Sci Rep. 2016; 6: 22172. DOI: 10.1038/srep22172.

19. Hoffman RM. Patient-derived orthotopicxenografts: better mimic of metastasis than subcutaneous xenografts. Nat Rev Cancer. 2015; 15: 451-2. DOI: 10.1038/nrc3972.

20. Tétreault MP. Esophageal cancer: insights from mouse models. Cancer growth and metastasis. 2015; 8: 37-46. DOI: 10.4137/ CGM.S21218.

21. Bhargava S, Hotz B, Buhr HJ, Hotz HG. An orthotopic nude mouse model for preclinical research of gastric cardia cancer. Int J Colorectal Dis. 2009; 24: 31-9. DOI: 10.1007/s00384-0080584-z.

22. Rostovcev NM, Kotljarov NA. Sravnitel'nyj analiz jeffektivnosti luchevogo i fotodinamicheskogo lechenija jeksperimental'noj opuholi. Pediatricheskij vestnik Juzhnogo Urala. 2015; 1: 29-32. Russian.

23. Kolesnikov EN, Kit SO, Lukbanova EA, Goncharova AS, Maksimov AYu, avtory. Federal'noe gosudarstvennoe bjudzhetnoe uchrezhdenie "Rostovskij nauchno-issledovatel'skij onkologicheskij institut" Ministerstva zdravoohranenija Rossijskoj Federacii, patentoobladatel'. Sposob ortotopicheskoj transplantacii kul'tury opuholevyh kletok pishhevoda cheloveka v shejnyj otdel pishhevoda immunodeficitnyh myshej. Patent RF 2713798. G09B 23/28. Zajavka \# 2019113616 ot 30.04.19. Russian.

24. Spiegelberg L, van Hoof SJ, Biemans R, Lieuwes NG, Marcus D, Niemans R, et al. Evofosfamide sensitizes esophageal carcinomas to radiation without increasing normal tissue toxicity. Radiother Oncol. 2019; 141: 247-55. DOl: 10.1016/j.radonc.2019.06.034.

25. Shi J-J, Xing H, Wang Y-X, Zhang X, Zhan Q-M, Geng M-Y, et al. $\mathrm{PI} 3 \mathrm{~K} \alpha$ inhibitors sensitize esophageal squamous cell carcinoma to radiation by abrogating survival signals in tumor cells and tumor microenvironment. Cancer Letters. 2019; 459: 145-55. DOI: 10.1016/j.canlet.2019.05.040.

26. Teicher BA, Andrews PA, editors. Anticancer Drug Development Guide. Preclinical screening, clinical trials, and approval. 2nd ed. Totowa, New Jersey: Humana Press; 2004. DOI: 10.1007/978-159259-739-0.

27. Treshhalina EM. Immunodeficitnye myshi Balb/c nude i modelirovanie razlichnyh variantov opuholevogo rosta dlja doklinicheskih issledovanij. RBZh. 2017; 16 (3): 6-13. DOI: 10.17650/1726- 9784-2017-16-3-6-13. Russian.

журнал. 2017; 16 (3): 5-11. DOI: 10.21294/1814-4861-2017-3$5-11$

6. Кит О. И. Нейроэндокринные, клинические и морфологические аспекты рака желудка. Новочеркасск: Лик, 2014; 221 с.

7. Ishihara R, Oyama T, Abe S, Takahashi H, Ono H, Fujisaki J et al. Risk of metastasis in adenocarcinoma of the esophagus: a multicenter retrospective study in a Japanese population. Journal of gastroenterology. 2017; 52 (7): 800-8. DOI: 10.1007/s00535016-1275-0.

8. Mahoney JL, Condon R. E. Adenocarcinoma of the esophagus. Annals of surgery. 1987; 205 (5): 557.

9. Урмонов У. Б., Добродеев А. Ю., Асанасьев С. Г., Августинович А. В., Черемисина О. В. Современные аспекты лечения рака пищевода. Сибирский онкологический журнал. 2019; 18 (4): 78-84. DOI: 10.21294/1814-4861-2019-18-4-78-84. 
10. Hidalgo M, Amant F, Biankin AV, Budinská E, Byrne AT, Caldas C, et al. Patient-derived xenograft models: an emerging platform for translational cancer research. Cancer Discov. 2014; 4: 998-1013. DOI: 10.1158/2159-8290.

11. Wilding JL, Bodmer WF. Cancer Cell Lines for Drug Discovery and Development. Cancer Res. 2014; 74 (9): 2377-84. DOI: 10.1158/0008-5472.CAN-13-2971.

12. Sung-Yup Cho. Patient-derived xenografts as compatible models for precision oncology. Laboratory Animal Research. 2020; 36: 14. DOI: 10.1186/s42826-020-00045-1

13. Zhuo J, Su R, Tan W, Lian Z, Lu D, Xu X. The ongoing trends of patient-derived xenograft models in oncology. Cancer Commun (Lond). 2020; 40 (11): 559-63. DOI: 10.1002/cac2.12096.

14. Fernandes DP, Pimentel MML, Santos FAD, Praxedes ÉA, Brito PD, Lima MA, Lelis ICNG, Macedo MF, Bezerra MB. Hematological and biochemical profile of BALB/c nude and C57BL/6 SCID female mice after ovarian xenograft. An Acad Bras Cienc. 2018; 90 (4): 3941-48. DOI: 10.1590/0001-3765201820180586.

15. Ж Жукова Г. В., Шихлярова А. И., Сагакянц А. Б., Протасова Т. П. О расширении вариантов использования мышей BALB/c nude для экспериментального изучения злокачественных опухолей человека in vivo. Южно-Российский онкологический журнал. 2020; 1 (2): 28-35.

16. Szadvari I, Krizanova O, Babula P. Athymic nude mice as an experimental model for cancer treatment. Physiol Res. 2016; 65 (Suppl 4): S441-53. DOI: 10.33549/physiolres.933526.

17. Pompili L, Porru M, Caruso C, Biroccio A, Leonetti C. Patientderived xenografts: a relevant preclinical model for drug development. J Exp Clin Cancer Res. 2016; 35 (1): 189. DOI: 10.1186/s13046-016-0462-4.

18. Choi YY, Lee JE, Kim H, Sim MH, Kim K.-K., Lee G, et al. Establishment and characterisation of patient-derived xenografts as paraclinical models for gastric cancer. Sci Rep. 2016; 6: 22172. DOI: 10.1038/srep22172.

19. Hoffman RM. Patient-derived orthotopicxenografts: better mimic of metastasis than subcutaneous xenografts. Nat Rev Cancer. 2015; 15: 451-2. DOI: 10.1038/nrc3972.
20. Tétreault MP. Esophageal cancer: insights from mouse models. Cancer growth and metastasis. 2015; 8: 37-46. DOI: 10.4137/ CGM.S21218.

21. Bhargava S, Hotz B, Buhr HJ, Hotz HG. An orthotopic nude mouse model for preclinical research of gastric cardia cancer. Int J Colorectal Dis. 2009; 24: 31-9. DOI: 10.1007/s00384-0080584-Z.

22. Ростовцев Н. М., Котляров Н. А. Сравнительный анализ эффективности лучевого и фотодинамического лечения экспериментальной опухоли. Педиатрический вестник Южного Урала. 2015; 1: 29-32.

23. Колесников Е. Н., Кит С. О., Лукбанова Е. А. Гончарова А. С., Максимов А. Ю., авторы. Федеральное государственное бюджетное учреждение "Ростовский научно-исследовательский онкологический институт" Министерства здравоохранения Российской Федерации, патентообладатель. Способ ортотопической трансплантации культуры опухолевых клеток пищевода человека в шейный отдел пищевода иммунодесицитных мышей. Патент РФ 2713798. G09B 23/28. Заявка № 2019113616 от 30.04.19.

24. Spiegelberg L, van Hoof SJ, Biemans R, Lieuwes NG, Marcus D, Niemans R, et al. Evofosfamide sensitizes esophageal carcinomas to radiation without increasing normal tissue toxicity. Radiother Oncol. 2019; 141: 247-55. DOl: 10.1016/j.radonc.2019.06.034.

25. Shi J-J, Xing H, Wang Y-X, Zhang X, Zhan Q-M, Geng M-Y, et al. PI3K $\alpha$ inhibitors sensitize esophageal squamous cell carcinoma to radiation by abrogating survival signals in tumor cells and tumor microenvironment. Cancer Letters. 2019; 459: 145-55. DOI: 10.1016/j.canlet.2019.05.040

26. Teicher BA, Andrews PA, editors. Anticancer Drug Development Guide. Preclinical screening, clinical trials, and approval. 2nd ed. Totowa, New Jersey: Humana Press; 2004. DOI: 10.1007/978-159259-739-0

27. Трещалина Е. М. Иммунодесицитные мыши Balb/c nude и моделирование различных вариантов опухолевого роста для доклинических исследований. РБЖ. 2017; 16 (3): 6-13. DOI: 10.17650/1726- 9784-2017-16-3-6-13. 